\title{
Validity and reliability of medication adherence scale in FMF
}

\author{
BE Fidanci, S Yesilkaya, C Acikel, A Ozden, D Simsek*, F Yildiz, B Kisacik, M Sayarlioglu, S Akar, S Senel, M Tunca, \\ S Yavuz, A Tufan, A Berdeli, AM Onat, A Gul, B Goker, T Kasifoglu, H Direskeneli, S Erten, G Ozcelik, F Gok, S Ozen, \\ E Demirkaya
}

From 8th International Congress of Familial Mediterranean Fever and Systemic Autoinflammatory Diseases Dresden, Germany. 30 September - 3 October 2015

\section{Objective}

The optimal level of adherence necessary to achieve acceptable disease and quality-of-life outcomes for patients is not known. In order to identify these optimal levels, we need reliable and valid measures of adherence. Medication Adherence Scale in FMF (MASIF) is an instrument designed to measure adherence to treatment in children with Familial Mediterranean Fever (FMF). We have developed this scale for children with FMF and found valid and reliable. In this study, it was aimed to assess the validity and reliability of this adherence scale for medical treatment in adult FMF patients.

\section{Methods}

This study is multicentre and 14 centers participated to the study. Patients with FMF using medication at least for 6 months and accepted to participate constituted the sample of the study. Besides "Medication Adherence Scale in FMF Patients (MASIF)", "Data collection forms about the sociodemographic and medical information (demographic, clinical and laboratory findings) of patients", and "Morisky Medication Adherence Scale (MMAS)" were used as data collection instruments. Morisky medication adherence scale was used as a gold standard in order to evaluate the criterion validity of MASIF. We assessed the validity of the adult version of the MASIF using the Outcome Measures in Rheumatoid Arthritis Clinical Trials (OMERACT) filter.

\section{Results}

There were 133 patients with FMF enrolled for the validation of the study. The median age of the patients

\footnotetext{
FMF Arthritis Vasculitis and Orphan Disease Research in Paediatric
} Rheumatology (FAVOR), Ankara, Turkey

C 2015 Fidanci et al. This is an Open Access article distributed under the terms of the Creative Commons Attribution License (http:// creativecommons.org/licenses/by/4.0), which permits unrestricted use, distribution, and reproduction in any medium, provided the original work is properly cited. The Creative Commons Public Domain Dedication waiver (http://creativecommons.org/publicdomain/ zero/1.0/) applies to the data made available in this article, unless otherwise stated.

\section{Conclusion}

Approximately $10-15 \%$ of patients with FMF are nonresponders but it was claimed that in fact they are noncompliers that causes these patients receive unnecessary biologic agent treatment procedures, which are expensive and have some serious adverse effects. This scale will provide assessment and follow up of adherence to treatment patients and determine whether the patient is non-responders or non-compliers. It may help to determine the non-compliance and prevent unnecessary and expensive biologic agents. 
- Convenient online submission

- Thorough peer review

- No space constraints or color figure charges

- Immediate publication on acceptance

- Inclusion in PubMed, CAS, Scopus and Google Scholar

- Research which is freely available for redistribution 